\title{
Redescription of Travassiella avitellina Rego \& Pavanelli, 1987 (Proteocephalidea: Monticelliidae, Zygobothriinae), a Parasite of Paulicea luetkeni (Siluriformes) from South America
}

\author{
Alain de Chambrier, Alicia Alida Gil de Pertierra*/+ \\ Département des Invertébrés, Muséum d'Histoire Naturelle, Geneva, Switzerland *Departamento Ciencias Biológicas, Lab. 52 , \\ Facultad de Ciencias Exactas y Naturales, Pab. II, Ciudad Universitaria, C1428EHA, Buenos Aires, Argentina
}

The genus Travassiella Rego \& Pavanelli, 1987 comprises only one species, T. avitellina Rego \& Pavanelli, 1987; characterized by these authors on the basis of absence of vitelline follicles. In this study, the presence of cortical vitelline follicles in this species is confirmed after de Chambrier and Vaucher (1999); the redescription was performed for the first time based on type and new material collected from Argentina, Brazil and Paraguay. Travassiella is confirmed as a valid genus, and compared to other genera of the subfamily Zygobothriinae. T. avitellina is characterized by: (1) the presence of gland cells posteromedially to suckers; (2) the particular distribution of vitelline follicles, forming lateral arches; (3) uterine primordium cortical, growing into medulla and forming a saclike uterus; (4) eggs, irregularly oval, outer envelop with excrescences and two digitate lappets in one of the poles.

Key words: Travassiella avitellina - cestode - Pimelodidae - Argentina - Paraguay - Brazil

The cestode genus Travassiella Rego \& Pavanelli, 1987 (Proteocephalidea) comprises only one species, Travassiella avitellina Rego \& Pavanelli, 1987 (Rego 1994). The adult worm parasitises the intestine of Paulicea luetkeni (Steindachner, 1876), one of the largest siluriform fishes that inhabits the Amazon and Paraná basins (Ringuelet et al. 1967, Vazzoler et al. 1997).

The taxonomy of Proteocephalidea Mola, 1928 at the family and subfamily levels has its foundations in the relationship of the reproductive organs to the internal longitudinal muscle bundles. Thus, cross sections of the proglottides are necessary to determine the relative position of the organs. The relationship of vitelline follicles to the internal longitudinal muscles is fundamental in the subdivision into families. The Proteocephalidae La Rue, 1911 has medullary vitelline follicles while the Monticelliidae La Rue, 1911 has cortical vitelline follicles. The subfamilies of the Proteocephalidae are separated generally by the characteristics of the scolex, but in all of them (except Marsypocephalinae Woodland, 1933) the genital organs are in the medulla. Rego and Pavanelli (1987) included Travassiella in the Proteocephalinae Mola, 1929 based on the medullar condition of the genitalia, and the absence of vitelline follicles. De Chambrier and Vaucher

Financial support: ANPCyT (Proj. BID 1201 OC-AR PICT no. 1-6604) and CONICET (Proj. PIP 4545/96)

${ }^{+}$Corresponding author. Fax: +54-11-4576.3384. E-mail: helminto@bg.fcen.uba.ar

Received 12 November 2001

Accepted 14 March 2002
(1999) observed the presence of vitelline follicles in the cortex of the proglottis in T. avitellina and transferred this species to Zygobothriinae Woodland, 1933, within Monticelliidae.

T. avitellina is redescribed in detail for the first time in this paper, based on type and new material collected from Argentina, Brazil and Paraguay.

\section{MATERIALS AND METHODS}

Twenty four specimens of $P$. luetkeni from Brazil, five from Argentina, and one from Paraguay were examined for helminths. Worms found in the intestine were isolated and fixed in hot $4 \%$ formaldehyde solution and stored in $75 \%$ ethanol. Entire tapeworms were stained with Mayer's hydrochloric carmine (modified from Langeron 1949), differentiated in acid ethanol, dehydrated through a gradual ethanol series, cleared with Eugenol or beechwood creosote and mounted as whole mounts in Canada balsam. Thick cross hand-cutting sections of the proglottides were stained following the same procedure; fragments of the strobila were embedded in paraffin wax, transversely sectioned at 13-19 $\mu \mathrm{m}$, stained with Weigert's hematoxylin and counterstained with $1 \%$ eosin $\mathrm{B}$ and mounted in Canada balsam (see de Chambrier 2001). Eggs were mounted in distilled water, after fixation for drawing. Whole mounts were studied using Nomarski interference contrast in a Zeiss Axioskop microscope. All drawings were made with the aid of a camera lucida. Type specimens of T. avitellina housed at Helminthological Collection of Instituto Oswaldo Cruz, Rio de Janeiro, Brazil (CHIOC), voucher specimens housed at Natural History Museum, Geneva, Switzerland (INVE), and at the Museo Argentino de Ciencias Naturales "Bernardino Rivadavia", Buenos Aires, Argentina (MACN) were studied. All measurements are given in micrometers, unless otherwise stated, with the range followed by the mean, standard deviation and the number of measurements ( $\mathrm{n})$ in parentheses. 


\section{RESULTS}

MONTICELLIIDAE La Rue, 1911

ZYGOBOTHRIINAE Woodland, 1933

Travassiella avitellina Rego \& Pavanelli, 1987

(Figs 1-8)

Type host: Paulicea luetkeni (Steindachner, 1876) (Siluriformes: Pimelodidae), common name: manguruyú (Argentina) and jaú (Brazil).

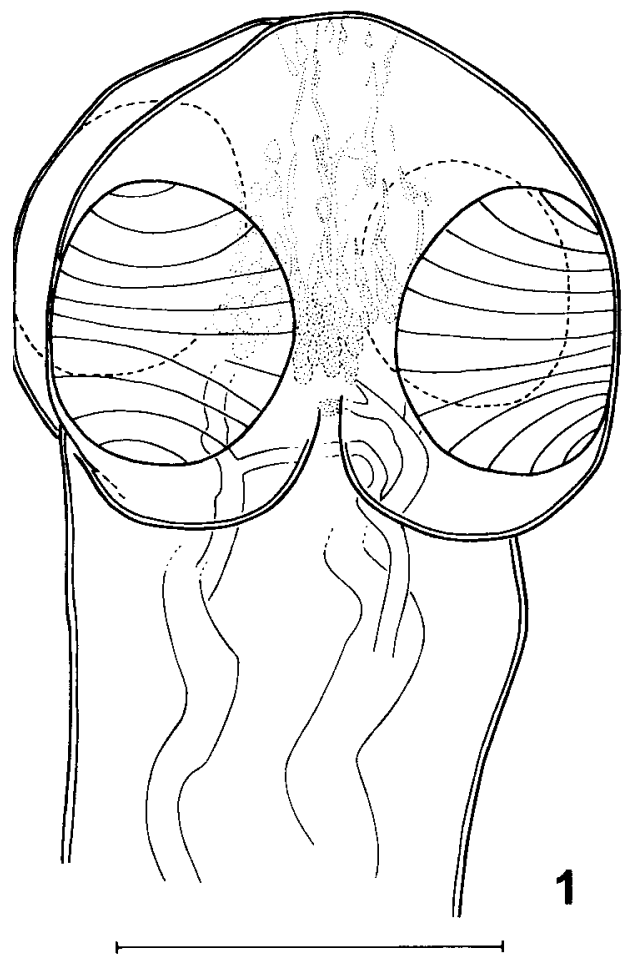

Site of infection: middle and posterior part of intestine. Type material: holotype CHIOC 32.259 and CHIOC 32.260 a-b, Itaipu Reservoir, Paraná river, State of Paraná, Brazil; Salobra, State of Mato Grosso, Brazil, and Pirassununga, State of São Paulo, Brazil.

Other material: (1) INVE 18779, Pirassununga, Mogi Guaçú river, State of São Paulo, Brazil, INVE 16662, Itaipú Reservoir, Paraná river, State of Paraná, Brazil (type locality),
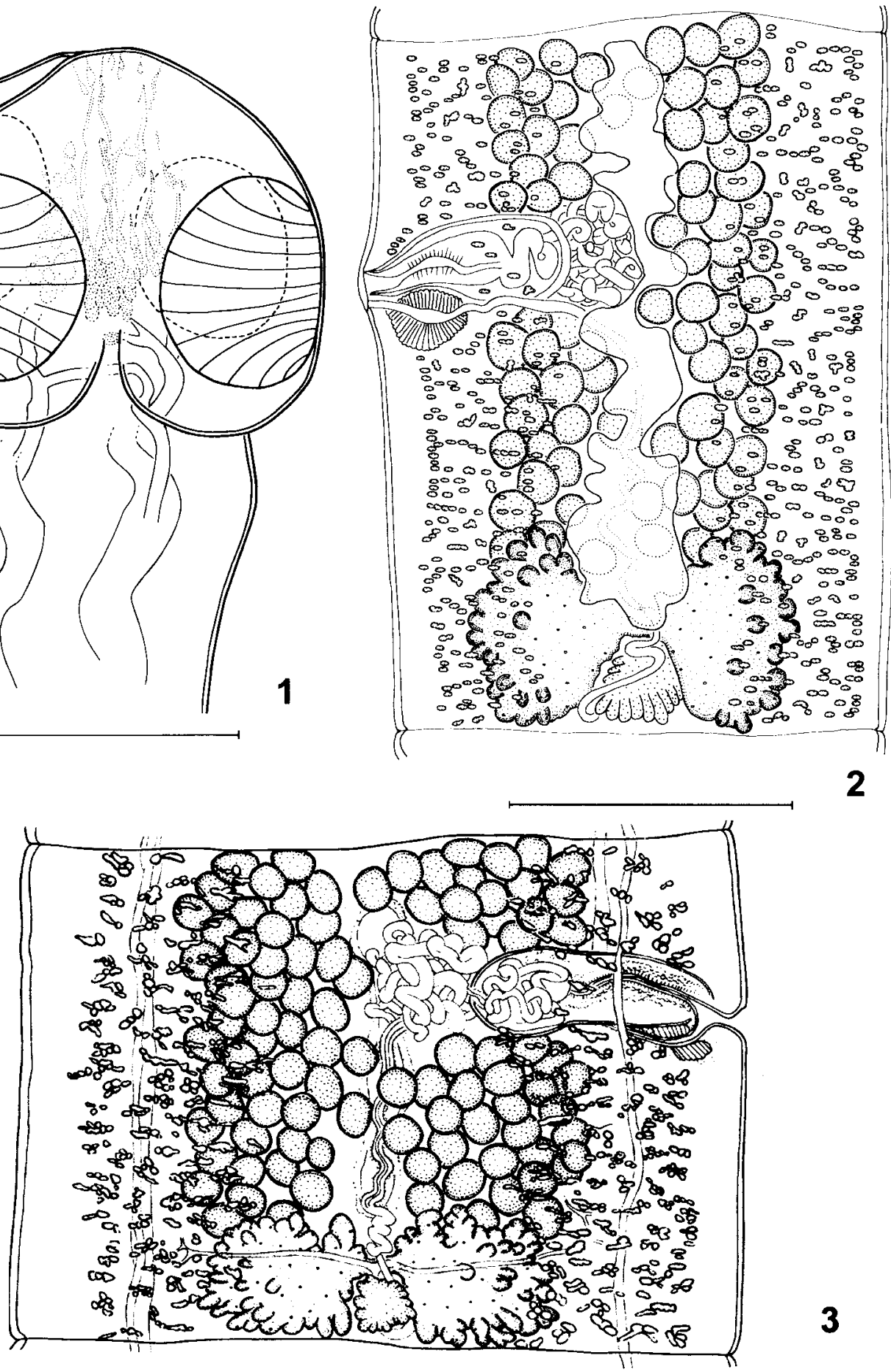

Travassiella avitellina Rego \& Pavanelli, 1987. Fig. 1: scolex, showing the elongate bottle shape gland cells. Bar $=250 \mu \mathrm{m}$. Fig. 2: gravid proglottis, ventral view. Bar $=500 \mu \mathrm{m}$. Fig. 3 : mature proglottis, dorsal view. Bar $=500 \mu \mathrm{m}$ 
INVE 19316, Itacoatiara, State of Amazonas, Brazil; (2) INVE 19315, Paraguay river, San Antonio, Central Department; (3) MACN, 402/1-3, Paraná river, Puerto Italia, Ciudad de Corrientes, Corrientes Province, Argentina.

Prevalence: Brazil, 83\% ( $n=24)$; Argentina, $40 \%(n=5)$; Paraguay, $100 \%(\mathrm{n}=1)$.

Description (based on ten specimens and measurements on seven specimens): testes, ovary, uterus medullary, vitelline follicles cortical. Worms of medium size $67-120 \mathrm{~mm}$ total length, flattened dorsoventrally. Strobila acraspedote, bearing 170-235 proglottides, 110-170 immature proglottides, 16-23 mature proglottides, and 38-44 gravid proglottides.

Scolex wider than proliferation zone, 220-430 (303 \pm $81 ; \mathrm{n}=7$ ) wide; elongate bottle shape gland cells with granular inclusions are situated posteromedially to the suckers, ducts of gland cells directed anteriorly to apex of scolex. Suckers uniloculate, strongly muscular, 120-190 $(153 \pm 23 ; n=15)$ long, $100-170(116 \pm 23)$ wide (Fig. 1$)$. Proliferation zone, 7-12 mm long, 220-300 wide.

Immature proglottides wider than long, 230-540 (389 \pm $103 ; \mathrm{n}=20)$ long, $360-850(577 \pm 130)$ wide; mature proglottides wider than long or longer than wide (Fig. 3), 490$930(772 \pm 127 ; \mathrm{n}=30)$ long, 630-1240 (922 \pm 161$)$ wide; gravid proglottides wider than long or longer than wide (Fig. 2), 700-1390 (947 $\pm 147 ; \mathrm{n}=40$ ) long, 780-1200 (932 \pm 107) wide.

Osmoregulatory canals very thin, between testes and vitelline follicles (Figs 3, 5-6), dorsal canal 2-4 in diameter, ventral canal 5-7 in diameter. Internal longitudinal musculature poorly developed, forming slim and isolate bundles, 8-14 fibre bundles (Figs 4-6) in the proglottides.

Testes medullary, total number $54-113(85 \pm 13 ; \mathrm{n}=48)$ per mature proglottides, $45-70(58 \pm 7 ; \mathrm{n}=57)$ in diameter,
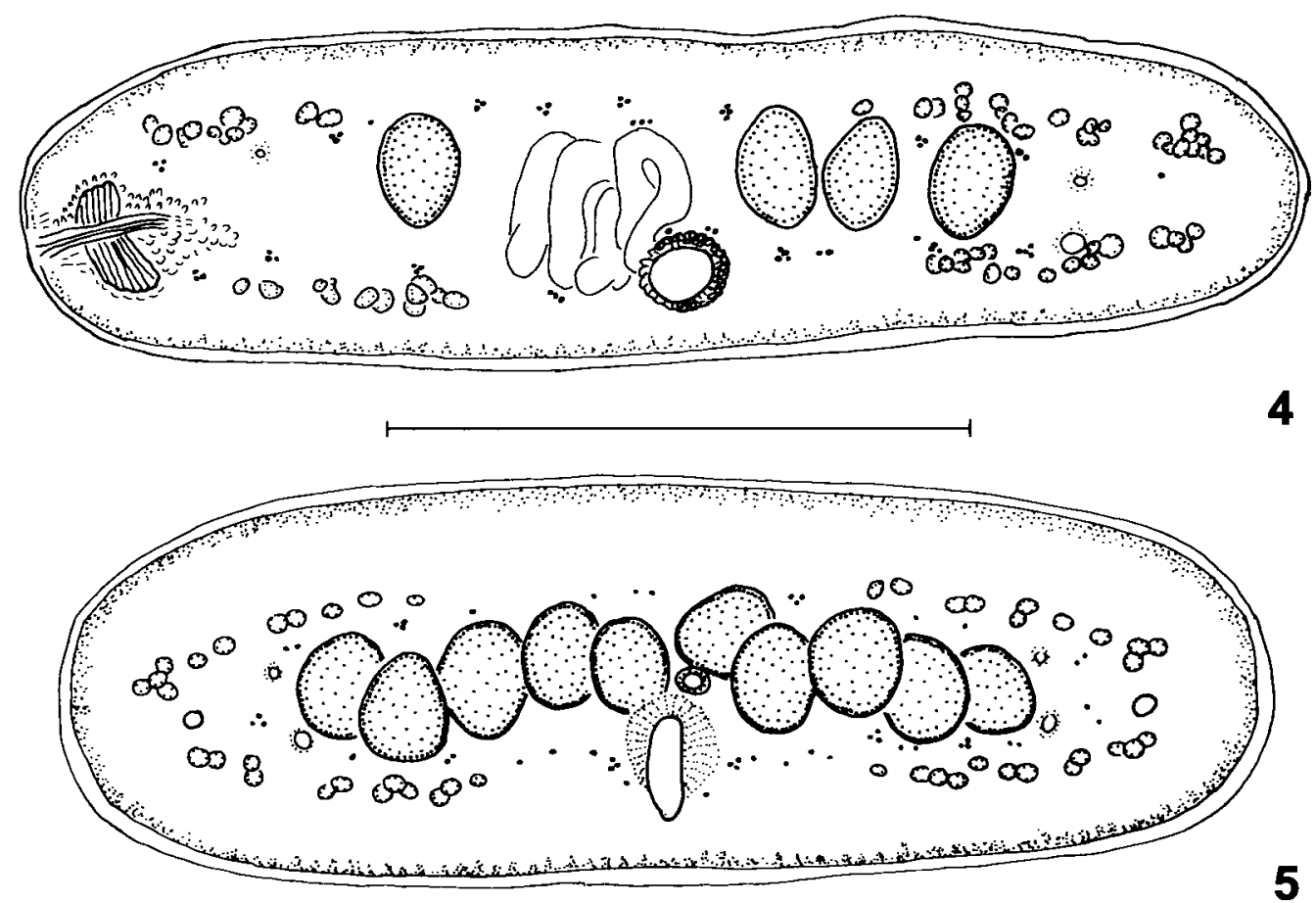

4

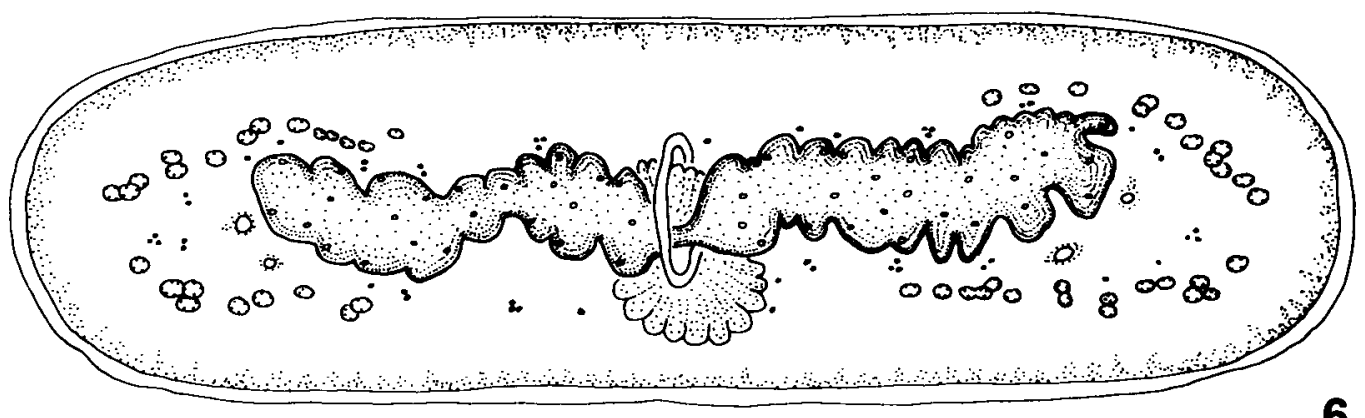

Travassiella avitellina Rego \& Pavanelli, 1987. Cross-sections of mature proglottides, showing internal longitudinal musculature, osmoregulatory canals and cortical vitelline follicles forming lateral arches. Fig. 4: cross-section at level of vagina, showing muscular sphincter and cortical uterus. Bar $=500 \mu \mathrm{m}$. Fig. 5: cross-section posterior to cirrus pouch and anterior to ovary, showing testes and vaginal duct, and the development of uterus into medulla. Fig. 6: cross-section at level of ovary, showing Mehlis'glands. Bar $=500 \mu \mathrm{m}$ 
in one dorsal field, in one or two layers (Figs 3, 5), interrupted by cirrus pouch and vas deferens along the proglottis. Cirrus pouch pyriform to oval, with thick muscular wall, 260-420 (326 $\pm 37 ; \mathrm{n}=40)$ long, 80-130 (115 \pm 12$)$ wide, occupying $32-46 \%(35 \pm 3 ; n=40)$ of proglottis width in mature proglottides. Genital pores irregularly alternating, $21-40 \%(31 \pm 4 ; \mathrm{n}=29)$ from anterior margin of mature proglottis, and $26-45 \%(34 \pm 4 ; \mathrm{n}=40)$ from anterior margin of gravid proglottis. Vas deferens coiled, 25-37 in diameter, rarely surpassing body midline in mature proglottides (Figs 2-3).

Vagina thin-walled, anterior $62 \%(\mathrm{n}=285)$ or posterior $38 \%(\mathrm{n}=173)$ to cirrus pouch, small differences in these percentages were recorded in specimens from different localities, $68 \%$ and $32 \%$ in specimens from Paraná river (Argentina), 66\% and 34\% in Paraná river (Brazil, type specimens), $70 \%$ and 30\% in Amazonia (Brazil), and 52\% and $48 \%$ in Paraguay river (Paraguay) respectively. Vaginal duct 10-15 in diameter, conspicuous muscular sphincter present (Figs 2-4). When vaginal duct is anterior to cirrus pouch, ventrally overlaps the vas deferens. Ovary medullar, bilobed and strongly lobulated, small outgrowths reaching the cortex exceptionally; ovary width in mature proglottides $420-460(547 \pm 61 ; \mathrm{n}=40)$, occupying $46-70 \%$ $(60 \pm 7 ; n=40)$ of proglottis width. Mehlis' glands voluminous, $70-150(103 \pm 18 ; \mathrm{n}=19)$ long, 100-220 (136 \pm 30$)$ wide in mature proglottides, occupying $16-27 \%$ of proglottis width. Vitelline follicles in cortex, diffuse and scanty chromophil, in two lateral arches occupying the whole proglottis length (Figs 2-3). Vitelline follicles distributed forming lateral arches extending towards the central part of proglottis in cross sections, extending up to $31-36 \%$ of proglottis width on each side (Figs 2-6). Follicles spherical to oval, with hyaline wall, several lumens included and non-chromophil granular structure (Fig. 7); partially overlapping testes and ovarian lobes but not reaching the uterus; not interrupted by vagina and cirrus pouch.

Uterine primordium originated as a cortical cylindrical mass of chromophil cells in immature proglottides, growing dorsally from the cortical stem into the medulla. Uterus sac-like, without developing uterine branches in mature and pregravid proglottis, with indistinct lateral branches in gravid proglottis (Fig. 2), slightly overlapping the ovary in gravid proglottides, reaching 20-50\% $(30 \pm 9 ; n=31)$ of gravid proglottis width. Eggs released by a ventral longitudinal slit. Oncosphere 12-14 (13 $\pm 0.9 ; \mathrm{n}=20)$ long, 9-11 $(10 \pm 0.6 ; \mathrm{n}=20)$ wide; oncosphere hooks 4-6 (5.5 $\pm 0.3 ; \mathrm{n}$ $=15)$ long; embryophore bilayered, $24-26(25 \pm 0.6 ; n=20)$ in diameter, thick, irregular oval shape outer envelope 46$70(61 \pm 6 ; n=20)$ long, with excrescences in both poles, one of the poles having two digitate lappets (Fig. 8).

\section{DISCUSSION}

De Chambrier and Vaucher (1999) have demonstrated the presence of vitelline follicles in T. avitellina, contrary to the observations of Rego and Pavanelli (1987, p. 358 and 359) and Rego (1994, p. 261). Moreover, the absence of vitelline follicles was the main criterion that led Rego
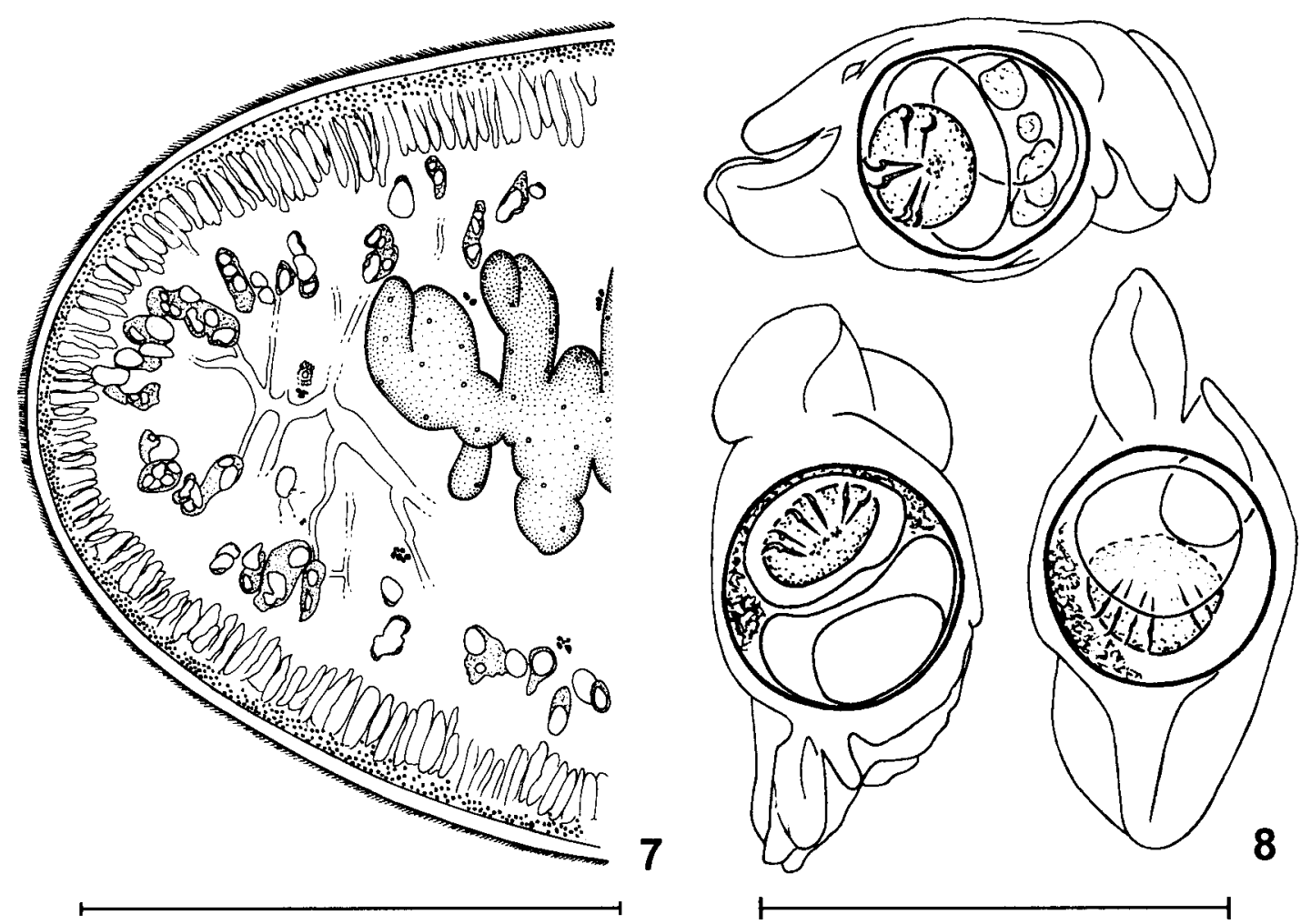

Travassiella avitellina Rego \& Pavanelli, 1987. Fig. 7: detail of vitelline follicles, showing the lumens and non-chromophil granular structure. Bar $=250 \mu \mathrm{m}$. Fig. 8: eggs drawn in distilled water, after fixation. Bar $=50 \mu \mathrm{m}$ 
and Pavanelli (1987) to propose the genus Travassiella. Lately, Rego et al. (1999) observed vitelline follicles in gravid proglottides. However, the vitelline follicles are in the cortex of the proglottis and therefore the genus has been placed in the Zygobothriinae by de Chambrier and Vaucher (1999).

From the 9 genera included in the subfamily Zygobothriinae, 4 have uniloculate suckers: Nomimoscolex Woodland, 1934; Postgangesia Akhmerov, 1969; Travassiella and Vaucheriella de Chambrier, 1987. Travassiella differs from Postgangesia by the absence of a rostellum-like apical organ, and from Vaucheriella by lacking postequatorial vitelline follicles. Travassiella is most similar to Nomimoscolex by the combination of the following characters: (1) uterus ontogeny, the formation of uterine primordium as a cortical cylindrical mass of chromophil cells; then, the uterus penetrates into medullar parenchyma through longitudinal internal musculature as described in N. suspectus Zehnder et al., 2000, N. piraeeba Woodland, 1934 and N. dorad (Woodland, 1935) by de Chambrier and Vaucher (1999) and Zehnder et al. (2000); (2) ovary exceptionally with slight dorsal outgrowths reaching the cortex; (3) vagina anterior or posterior to cirrus pouch; (4) cirrus without spines. Travassiella differs from Nomimoscolex by: (1) the distribution of vitelline follicles, in Nomimoscolex they are cortical or paramuscular, and distributed laterally not extending dorso-ventrally, but in Travassiella they are forming lateral arches towards the central part of proglottis in cross sections, except in median part occupied by the uterus, this feature is unique among the proteocephalideans. Likewise, it is very curious that the vitelline follicles are not stained with the routine stainings as the carmines or hematoxyline, and for this reason they are not easy to observe in whole mounts of proglottides. However, the vitelline follicles can be observed in cross sections of the proglottides as hyaline-yellow diffuse spherical to oval masses of follicles; (2) the development of the uterus into the medulla is different in both genera, the uterus is saclike in mature and pregravid proglottides of Travassiella, and forming conspicuous lateral branches in Nomimoscolex; (3) the eggs in Nomimoscolex are of typical shape, with approximately spherical outer envelope, but in Travassiella the outer envelope is irregularly oval with excrescences and two digitate lappets in one of the poles.

On the basis of the differences observed we confirm Travassiella as a valid genus and its inclusion in the subfamily Zygobothriinae. Moreover, the ranges of measurements, the mean, the standard deviation, and drawings of cell glands in the scolex, cross-section of the proglottides at different levels, detail of vitelline follicles and eggs are presented for the first time.

\section{ACKNOWLEDGEMENTS}

To Dr Verónica Ivanov for valuable suggestions and for her help in improving the English of the manuscript. To Dr Dely Noronha, at Instituto Oswaldo Cruz, for the loan of specimens.

\section{REFERENCES}

De Chambrier A 2001. A new minute tapeworm from the Amazon, Amazotaenia yvettae gen. n., sp. n., (Eucestoda: Proteocephalidea) from the siluriform fishes Brachyplatystoma filamentosum and B. vaillanti (Pimelodidae). Rev Suisse Zool 108: 303-316.

De Chambrier A, Vaucher C 1999. Proteocephalidae et Monticelliidae (Eucestoda: Proteocephalidea) parasites de poissons d'eau douce au Paraguay, avec descriptions d'un genre nouveau et de dix espèces nouvelles. Rev Suisse Zool 106: $165-240$.

Langeron M 1949. Précis de Microscopie, 7th ed., Masson \& Cie, Paris, $1429 \mathrm{pp}$

Rego AA 1994. Order Proteocephalidea Mola, 1928. In LF Khalil, A Jones, RA Bray (eds), Keys to the Cestode Parasites of Vertebrates, CAB International, Wallingford, UK, p. 257-293.

Rego AA, Pavanelli GC 1987. Cestóides proteocefalídeos do jaú, Paulicea luetkeni, peixe pimelodídeo do Brasil. Rev Brasil Biol 47: 316-357.

Rego AA, Chubb JC, Pavanelli GC 1999. Cestodes in South American freshwater teleost fishes: keys to the genera and brief description of species. Rev Brasil Zool 16: 299-367.

Ringuelet RA, Aramburu RH, Aramburu AA 1967. Los Peces Argentinos de Agua Dulce, Comisión de Investigación Científica, Provincia de Buenos Aires, La Plata, 602 pp.

Vazzoler AEA, Agostinho AA, Hahn NS 1997. A Planície de Inundação do Alto Rio Paraná: Aspectos Físicos, Biológicos e Socioeconômicos, Universidade Estadual de Maringá, Paraná, $460 \mathrm{pp}$.

Zehnder MP, de Chambrier A, Vaucher C, Mariaux J 2000. Nomimoscolex suspectus n. sp. (Eucestoda: Proteocephalidea, Zygobothriinae) with morphological and molecular phylogenetic analyses of the genus. Syst Parasitol 47: 157-172. 
